\title{
DESCRIPTION OF NEW SPECIES OF ANT (HYMENOPTERA : FORMICIDAE) FROM THE KHASI HILLS, MEGHALAYA
}

\author{
R. Mathew \\ Zoological Survey of India, Eastern Regional Station, Shillong, \\ Meghalaya, India
}

\begin{abstract}
Adstract. A new species of ant, Tetramorium barryi is being described from the Khasi Hills, Meghalaya, with a note on its food habit.
\end{abstract}

Bolton $(1976,1977)$ revised the genus Tetramorium Mayr of the Oriental, Indo-Australian and Australian Regions and recognised 72 species from the Oriental and Indo-Australian Regions. One new species is described here. All the measurements are given in millimetres and Bolton (1977) is followed for recognition of taxa. Type specimens will be deposited in the National Zoological Collections, Zoological Survey of India, Calcutta.

Genus Tetramorium Mayr

Tetramorium Mayr, 1855, Verh. zool. bot. Ver. Wien, 5 : 423. Type-species : Formica caespitum L.; designated by Girard, 1879.

Tetramorium barryi, sp. nov. (Figs. 1-4)

Holotype Worker, TL 2.45; HL 0.63, HW 0.55, CI 87, SL 0.42, SI 76, PW 0.42, AL 0.71 .

Head excluding the mandibles longer than broad, the occipital border slightly emarginate, the sides mildly convex. Compound eyes moderate, placed about the middle of the head laterally, maximum diameter of the eye 0.09. Anterior clypeal margin entire, clypeus convex in the middle. Mandibles finely striate. Frontal carinae distinct, reaching almost to the occipital border. Antennal scrobes distinct. Scape not reaching the occiput. Anterolateral angles of pronotum round. Propodeal spines about the size of the metapleural teeth, which are broader and acute. Petiole oval, about as long as broad, with a few faint striae dorsolaterally. Node of the petiole slightly longer than broad. Rugulation of head predominantly longitudinal, reticulate rugose, more so on the occiput. Alitrunk reticulate rugose. The petiole, post-petiole and gaster predominently smooth and shining. On the whole the insect has a shining appearance.

Colour : Head and body dark brown with a reddish tinge but mandibles, antennae and legs paler. 


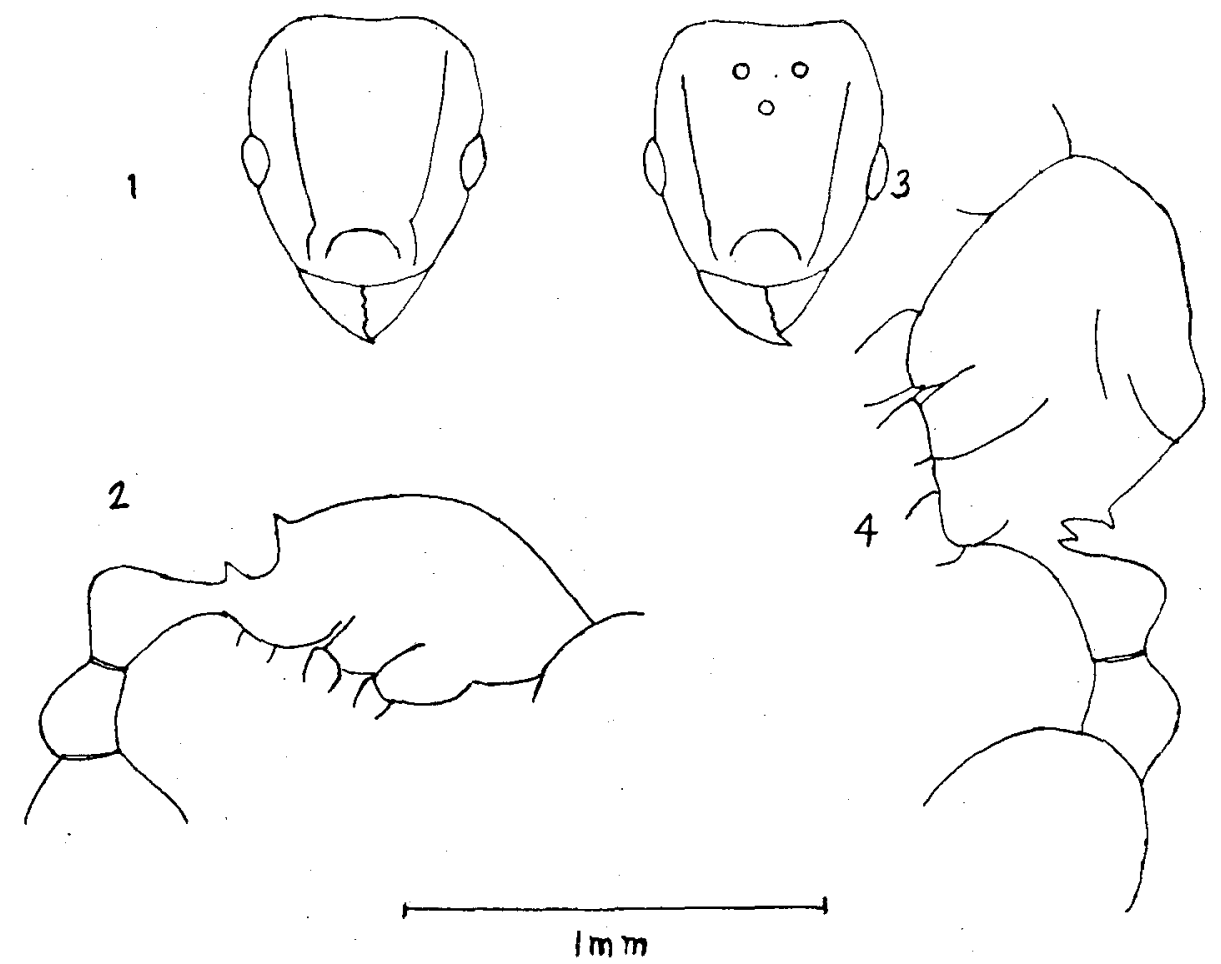

Figs. 1-4. Tetramorium barryi, sp. nov. : 1, Head of worker; 2, Alitrunk of the same; 3, Head of female; 4, Alitrunk of female.

Female : TL 3.0-3.1; HL 0.66, HW 0.61, CI 92, SL 0.41, SI 67, PW 0.54, AL 0.90 .

Agrees with the worker in all the morphological details but for its larger size and the modified alitrunk.

Paratype Workers : TL 2.32-2.61; HL 0.61-0.64, HW 0.55-0.58, CI 8488, SL 0.42-0.43, SI 74-79, PW 0.42-0.43, AL 0.67-0.71.

Similar to holotype but some specimens are darker brown to brownish-black.

Holotype worker : India : Meghalaya : Khasi Hills, Shillong, 15.iv.1977, Coll. R. Mathew. Paratypes : 10 workers and 2 females, collection data same as that of the holotype; 8 workers, Shillong, 25.vi.1975, Coll. R. Mathew; 3 workers, Shillong, 27.v.1976, Coll. R. Mathew; 9 workers, Shillong, 6.v.1976, Coll. R. Mathew; 10 workers, Shillong, 17.vi.1975, Coll. R. Mathew.

Tetramorium barryi is closely related to $T$. christiei Forel but can be distinguished by the smaller size, lighter coloration and almost same size of the propodeal spines and metapleural teeth. It is found to feed on insects, especially Collembola, Diplura, Diptera, Hemiptera and other Hymenoptera. Mites also form part of their food. They can be baited with bakery products, meat, etc. 
They nest on the ground under stones and crevices of buildings. Myrmecina striata Emery was observed in their nest.

ACKNowledgments. I am grateful to the Director, Zoological Survey of India, Calcutta and to Dr. Asket Singh, Deputy Director, Eastern Regional Station, Zoological Survey of India, Shillong, for necessary facilities. I wish to thank Dr. P.T. Cherian, Superintending Zoologist, Zoological Survey of India, Shillong for constant encouragement. Confirmation of the identity of this species is gratefully acknowledged to Dr. Barry Bolton, British Museum, London.

\section{REFERENCES}

Bingham, C.T. 1903. Fauna of British India, including Ceylon and Burma, Hymenoptera. 2. Ants and Cuckoo Wasps. 506 pp., 161 figs., 1 pl., London.

Bolton, B. 1976. The ant tribe Tetramoriini. Constituent genera, review of smaller genera and revision of Triglyphothrix Forel. Búll. Br. Mus. nat. Hist. (Ent.) 34 (5) : 281-379.

Bolton, B. 1977. The ant tribe Tetramoriini. The genus Tetramorium Mayr in the Oriental and Indo-Australian Regions, and in Australia. Bull. Br. Mus. nat. Hist. (Ent.) $36(2)$ : 67-151. 